\title{
Relationship between Mentoring, Self-Efficacy, Person Job-Fit and School Culture with Work Adjustment among New Teachers
}

\author{
Vichetera Rajagani@ Diwyaa ${ }^{1}$ \\ ${ }^{1}$ University Putra Malaysia, Serdang, Selangor, Malaysia \\ Correspondence: Vichetera Rajagani@ Diwyaa, University Putra Malaysia, 43400, Serdang, Selangor, Malaysia. \\ Tel: 60-1-7521-0833. E-mail: diwya09@yahoo.com
}

Received: May 17, 2014 Accepted: June 19, 2014 Online Published: July 24, 2014

doi:10.5539/ass.v10n16p90

URL: http://dx.doi.org/10.5539/ass.v10n16p90

\begin{abstract}
Adjustment is an important issue for all employees regardless of the industries in which they are in. These include those new teachers who fall within the education career category. The first few years of transition from being a trainee teacher to new teacher would call for these teachers to adjust themselves to new job requirements. New teachers are bound to deal with new tasks which they are unfamiliar with during teacher training. Hence, they need to adapt themselves to a different type of task, organizational culture and work environment. There are several factors that cause the early years of teaching being difficult. It is like teaching responsibilities, challenges of teaching, school culture, school climate and work environment that does not support. Each teacher had come from different circumstances, different backgrounds, and qualifications and they may vary. So it is clear that new teachers will need particular support in line with their needs. This conceptual paper proposes a new model of work adjustment to ensure better work adjustment for new teachers in Malaysian Public School. It is largely based on the Theory of Work Adjustment or TWA (Dawis \& Lofquist, 1984).
\end{abstract}

Keywords: mentoring, self-efficacy, person job-fit, school culture, work adjustment

\section{Introduction}

This study is about work adjustment by new teachers in Malaysia. The transition from teacher trainee to teachers serving in schools, creating work transformation. They called them new teachers or novice teachers. The influence of the school context and background of individual personal experience during pre-service education are variables identified as significant contributors in the initial evaluation of their teaching experience (Flores $\&$ Day, 2006). The transition from teacher trainee to new teacher should not be something that is problematic or difficult. Yet there are many studies shows that new teachers faced the reality of this shock, challenges, workloads, conflict and self-adjustment problems. Studies in the country and abroad shows new teachers still find difficulties to adapt to their profession (Dropkin \& Taylor, 1963).

The success of a new teacher to adjust and get used to the new situation of the environment is important for career development in the teaching profession (Hoffman, Edwards, O’Neal, Barnes, \& Paulissen, 1986). Various views and opinions presented to explain the emergence of problems faced by new teachers. Master of education Corcoran (1981) and Veenman (1984) attributed the problems experienced by new teachers with a concept of reality shock to explain the difference between the expected job duties with the reality in schools.

New teachers in schools also often have trouble in the beginning of their career because they are not being able to apply the knowledge learned during the institution in a real classroom. The tendency of a control and plan adjustment changes experienced in career and the work duties or work responsibilities reflects the extent of the degree of capacity or ability to work adjustment of an individual.

Mentoring, Self-Efficacy, Person Job- Fit and School Culture are the focused perspective by researchers working on the work adjustment of new teachers (Figure 1). These variables could identify the findings and contribute usefulness of the results obtained in this study. 


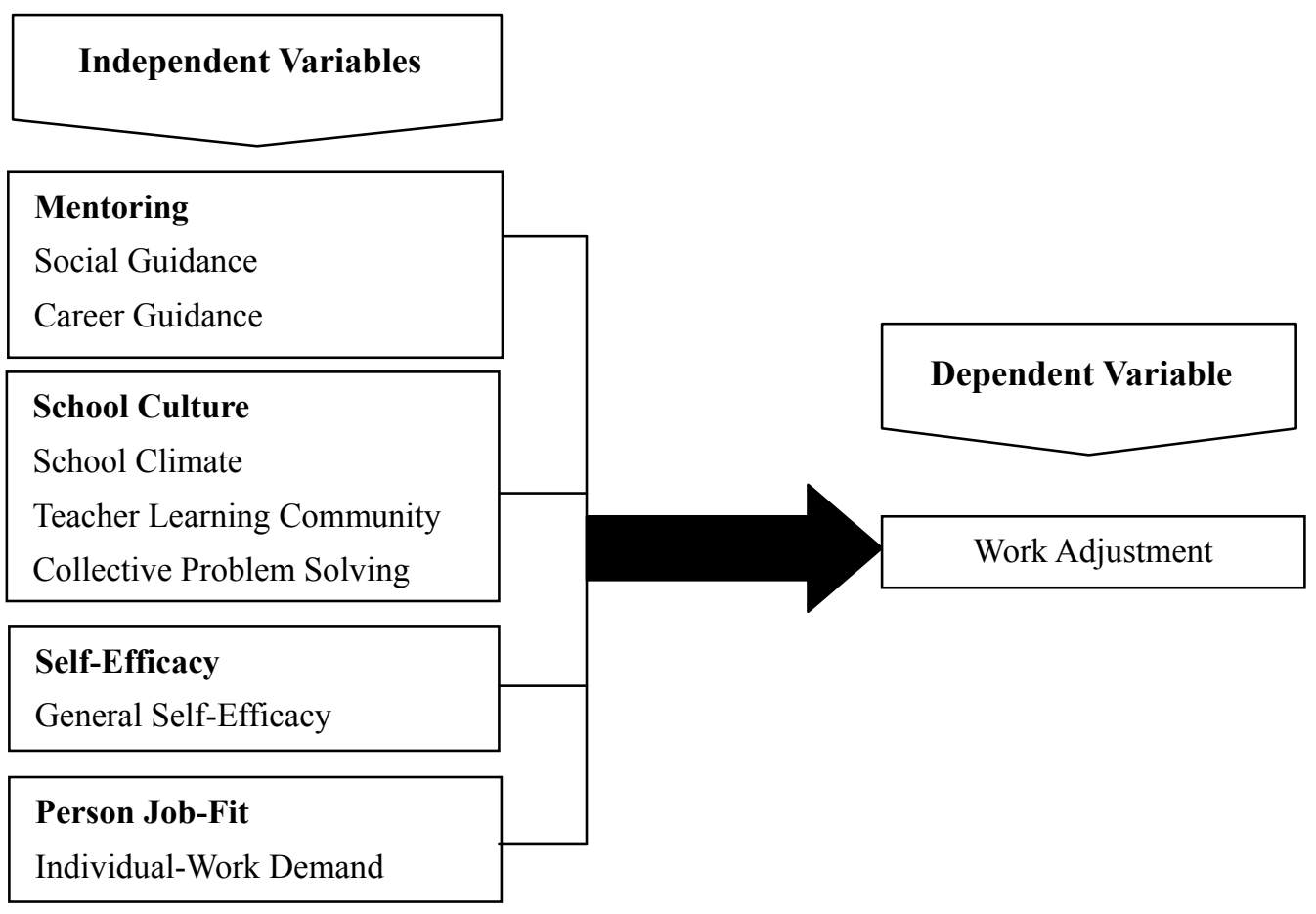

Figure 1. Research framework for measuring relationship between mentoring, self-efficacy, person job-fit and school culture with work adjustment among new teachers

\section{Definition of Work Adjustment}

Work adjustment is a dynamic and ongoing process since employees will strive to achieve and maintain compliance with its working environment (Lofquist \& Dawis, 1969). Black (1988) defines work adjustment as the work of individuals in a psychological comfort to face the various aspects of such supervisory responsibilities and other tasks in a new situation. Work adjustment also means the situation where an employee feels comfortable playing a new role and able to adjust to the standards and expectations of job performance (Aryee, Wyatt, \& Stone, 1996). Thus in this research, the author defines work adjustment as a subjective evaluation of new teachers about their ability to adjust themselves to the demands of work, job performance standards and offer rewards in the new work environment. It is measured using the Work Adjustment Scale by Black (1988).

\section{Theory of Work Adjustment}

Theory selected in this study is Theory of Work Adjustment by Dawis \& Lofquist (1984). This theory represents the perspective of Work Adjustment, Mentoring, Self-Efficacy, Person Job-Fit and School Culture. Figure 2 shows a brief overview of the Theory of Work Adjustment by Dawis \& Lofquist (1984). It was originally developed by Rene 'Dawis, Lofquist Lloyd George of England from University of Minnesota in 1964. Fundamental concept of the theory is based on the similarity and compatibility between individual factors and organizational environmental factors. This means mutually responsive interaction arises from the order and harmony of the compatibility of the individual to the environment and the environment on the individual. Good responsiveness between the two can complement the exacting requirements of the individual to his surroundings, and also to continue to survive, the individual has to reach a certain level to get you the suitability of the environment. 


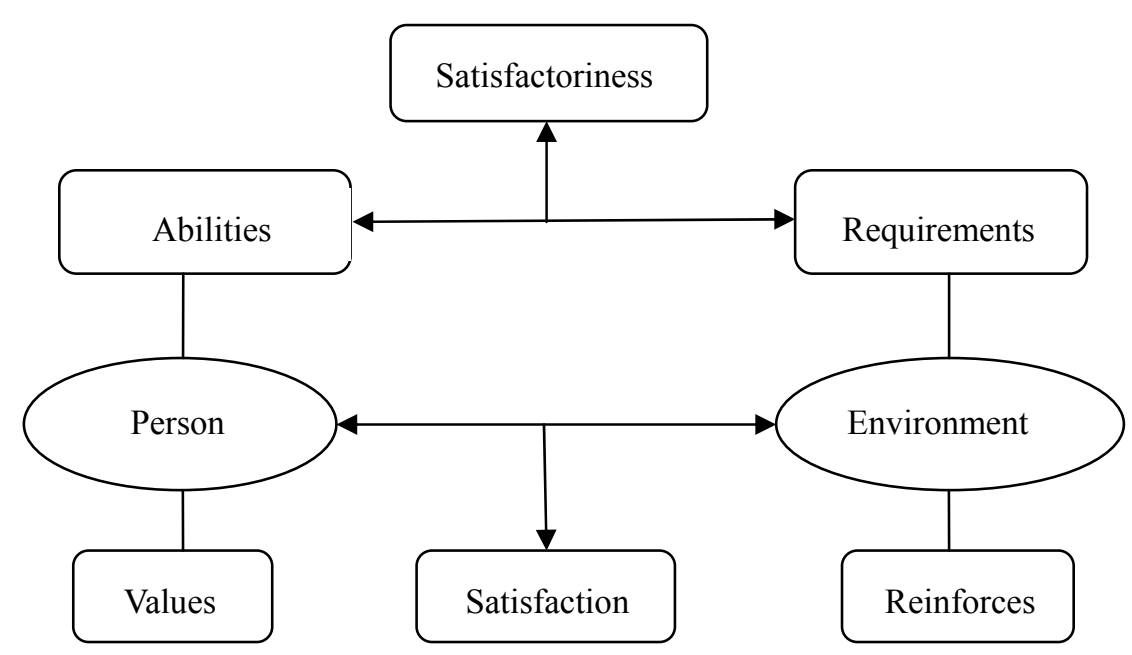

Figure 2. Theoretical framework of work adjustment

This theory is supported by the assumption that individuals need to find a suitable gain equation and remains compatible with its surroundings. Dawis and Lofquist focus on the work environment because majority of individuals faced to deal with the situation. When individuals first enter the world of work, their aims are more focused to meet the working environment needs where certain skills that prepare them well adjusted to the work environment. Work environment complete certain rewards (salary, prestige, personal relationships) needed by the individual. Therefore matching the skills of the individual to his work is the individual response to meet the demands of the work environment (e.g. rewards). The work environment is constantly changing. Change is a dynamic and ongoing process that occurs in individuals and organizations in response to the current and future needs. Thus based on this theory, a dynamic and continuous process for obtaining and maintaining compatibility and similarity of individual work environment is defined as "work adjustment" (Lofquist \& Dawis, 1969). In fact, the stability of the similarity and equivalence of individual and work environment can be explained and described based on the duration or length of service of an individual in his work.

Similarities and correspondence skills of an individual, to complete and fulfill demands of the work environment can give satisfaction over his performance. Based on this theory, satisfactoriness and satisfaction indicate the level of individual success in achieving compatibility between self-preservation and the environment. Performance is an external indicator of compatibility (similarity) individual and his working environment. While satisfaction is an internal indicator of equivalence (equality) that can be seen through the assessment of an individual employee to the extent to which the work environment fulfill its requirements.

Theory of Work Adjustment describes the relationship between the individual and his environment. The key point in the theory of work adjustment are:

1) Work or employment conceptualized as the interaction between the individual and the work environment.

2) Working environment requires specific tasks performed and the individual brings certain skills to perform certain tasks.

3) For exchange individuals require compensation for the work performance and conditions of certain options, such as a safe and comfortable place to work.

4) Environment and the individual must meet each other on an ongoing basis to maintain interaction. The extent to which the needs of both are met can be called as correspondence.

5) Work adjustment is the process to achieve and maintain correspondence. Work adjustment is shown by the individual satisfaction with the work environment.

6) Satisfaction and performance aspects of satisfactoriness are the result of duration and duration is the first indicator in work adjustment. The duration can be predicted from work personality correspondence with the work environment.

7) Work personality and working environment can be described in terms of structure and style variables measured on the same dimension. 
According to this theory, the closer a person's ability (skills, knowledge, experience, attitude and behavior) in accordance with the requirements of the role or the organization, the more likely that they will do well and is considered to be satisfactory by the employer. Similarly, strengthening closer (rewards) role or organization in accordance with the values that are to be met by a person through their work, the more likely someone is going to see the task as satisfying. Based on the Theory of Work Adjustment, there are six core values set out to achieve satisfaction; (1) Achievement, (2) Comfort, (3) Status, (4) Generous, (5) Safety and (6) Autonomy.

Levels of satisfaction and performance are seen as a predictor of a person will remain in employment, succeed in it and accept progress. This theory recognizes that compatibility between the individual and the environment may not be perfect, because individuals may have chosen the wrong career or organization has chosen the wrong candidate. Even good compatibility may vary over time. People skills may be developed so that they become bigger role or priorities may change due to non-work commitments.

The nature of the work, the nature of the reward or the ability of employers to offer rewards to be changed. The flexibility of a person or the environment will determine the extent to which individuals can tolerate any lack of compatibility between the abilities and needs and-or values and strengthening (rewards). Flexibility will vary from individual to individual and from environmental sustainability. According to this theory, the internal and external factors affecting the level of flexibility. When the lack of compatibility is so large that the flexibility is no longer viable and ranked some of the adjustments will occur among individuals and organizations to meet the lack of compatibility.

In addition, Dawis \& Lofquist (1984) have developed the hypothesis that experience traveled through various activities, in the face of diversity jobs and innovation in doing things will improve an individual's style of work adjustment. Active adaptation by individuals to engage them to try to change or alter their work environment. They may try to change the content of the work and therefore needs behavior, to better reflect their abilities. In addition, they may try to change the rewards of work by applying for different rewards, such as better working conditions or greater responsibility. Enabled by environmental adaptation may involve through efforts to change the skills of employees through the change or hope in some way.

Inactively adaptation may involve individuals attempting to change their behavior to better suit the environment or to change their personal preferences or work values. Similarly, the environment can alter the responsibilities of the role that better suits the natural strength of the individual or change the reward to try to increase job satisfaction. Persistence is defined as the point where the individual or the environment will continue to try to adjust before giving up. When there is no adjustment that can be done, something more dramatic happens where the individual leaving their jobs or laid off. Hence, the relevance of this theory to mentoring, self-efficacy, person job-fit and school culture is based on how the adjustment is made because the constantly changing work environment requires that an employee should always be tolerant and adapt to his environment.

\section{Predictor's of Novice Teachers' Work Adjustment}

\subsection{Self-efficacy}

Efficacy or self-confidence means a person in the performance of his behavior to achieve a purpose to be successful. Although the concept of self-efficacy was first presented in the context of social psychology, but the ability of psychologists define this concept is by early definition by Bandura (1977). He defines self-efficacy as the degree of difficulty of a task for which the individual is of the opinion that the ability is sufficient to enable him to make a change. Bandura (1986) state self-efficacy influences performance by increasing effort and perseverance. Individuals with high self-efficacy work harder and able to work long hours compared with individuals with low self-efficacy (Wood \& Bandura, 1989).

Efficiency is also referring to an individual ability to achieve one goal. It is an assessment of the ability to organize and execute the sequence of presentation behavior required to achieve this aim (Bandura, 1982). Ramey-Gassert \& Shroyer (1992) argues that self-efficacy can be defined as one's confidence in the abilities available to him. Individual behavior in the context of an organization is strongly influenced by the interaction of the individual with the environment situation of his career. Individuals will adjust behaviors and actions to achieve the goals and 'outcomes' of the intended use (Bandura, 1977, 1986, 1997). This process is known as self-efficacy formation.

Gist, Mitchell, \& Mitchell (1992) emphasized self-efficacy as the assessment of an individual's ability to implement specific tasks. Gist (1992) outlines three key aspects of the concept of self-understanding. First, self-efficacy involves the consideration or 'comprehensive summary' by individuals to perform its specific tasks. In such organizations, the information "comprehensive summary" can be attributed to the individual himself, or 
the task to be performed, or information from other people in the organization. Second, self-efficacy involves a component of motivation and individual motivation. Third self-efficacy constructs a dynamic nature, and it changes according to the response or interaction to experience the environment and new information. Self-efficacy in individuals more concerned about the ability of individuals to balance demand and time pressure.

According to Ramey-Gassert \& Shroye (1992) self-efficacy can be defined as one's confidence in the abilities available to him. According to him, the belief in the ability of an individual is in itself can cause a person to act in a better and more accurate. Self-efficacy is defined as an individual's beliefs about their ability to perform a particular behavior or task successfully (Bandura, 1977). According to Bandura, the ability of an individual is determined by four principle sources of performance information (performance accomplishments), representing experience (vicarious experience), verbal persuasion (verbal persuasion) and psychological state (psychological states).

Self-efficacy is based on the individual's perception of certain behaviors and outcomes specific to them alone. For this reason, self-efficacy is considered as a particular situation and does not cross over from one aspect of the behavior of others (Bandura, 1986). Individuals can show the level of self-efficacy when engaging in certain behaviors. Four sources of self-efficacy are performance accomplishments, vicarious experience, verbal persuasion and psychological states. Self-efficacy is also often associated with job satisfaction, commitment, performance and job strain. This argument was voiced by Louis (1998) with the view self-efficacy is important because it involves effective controls of emotion by teachers and school administrators in facing problem and situations more rationally.

One's self-efficacy can lead to the formation of a variety of behavior when he is carrying out his duties. Self-efficacy in this study is defined as one's confidence on himself to perform the required tasks. In this study the researchers looked at the general self-efficacy. It is measured using 'Perceived Self-Efficacy Scale' (PSE) by Coppel, (1980).

\subsection{Mentoring}

Based on the new teacher's perspective, mentoring can be defined as the support and assistance of expert individuals with new individual or less experienced individual (mentee) by an experienced (mentor), aims to help the development of skills (mentee) and the practice of a profession (teaching) through a specific context (school or college) (Hobson, Ashby, Malderez, \& Tomlinson, 2009). Effective support through mentoring has helped to increase the retention of new teachers (Brill \& McCartney, 2008; Ingersoll \& Strong, 2011; Johnson \& Birkeland, 2003; Wilkinson, 2009). In addition, the definition of mentoring according to Anderson \& Shannon (1988) is: "a process of care that would mean that the occurrence of the development process where the mother acts as (model, sponsoring, encouraging, and counseling and befriends friendly) that he was able to identify abilities, a psychological experience and maturity in care and can provide activities that will lead to growth.

Attributes involved in the definition mentoring by Anderson \& Shannon (1988) is the first, the process of care (Nurturing). Mentors will provide an environment for personal growth, knowledge and personality (mentee) to provide all appropriate assistance. Second, act as role models. Mentors will provide an overview of the weaned on what happened. (Mentee) will be able to see some degree of maturity itself through other adult individuals (Levinson and colleagues, 1978). Various aspects of mentoring experience have demonstrated to have an impact on teach mentors themselves.

There is evidence through the study of learning mentors 'self-reflection or reflection-criticism' in their personal practice (Abell, 1995; Kwan \& Lopez-Real, 2005; Simpson, Hastings, \& Hill, 2007). Things will be a mirror of the (mentee) and should serve as required. Third, the five functions mentoring (teaching, sponsoring, encouraging, counseling and befriends friendly). Five functions are seen as 'conjunctive' (meaning mentors willing exhibits one of the five functions if needed). Fourth, professional and personal development. Programs of teacher professional development is important for new teachers to track the progress in the field of education, teaching and learning strategies and realizing the educational needs of the present. The last attribute is continuous loving relationship. The form of relationships that exist in mentoring can be considered the same as a good substitute parents as caring for their children. Mentoring can be defined as an activity performed with the intention of matching individuals who are inexperienced with experienced partners with a view to guide and nurture the development of the inexperienced individuals (Pitton, 2006). Pitton also noted mentoring is a key strategy to help new teachers to succeed in the navigation routes and methods into a profession.

In this research mentoring is defined as the perception of a new teacher about the relationship with a mentor who 
carried major role on the effectiveness of the implementation of mentoring program at the school. It consists the dimensions of career guidance and social guidance which specifically focused on social perceptions of mentees (new teachers) to mentor. These dimensions are measured using 'Mentoring Survey Instruments' by Wakeham (2003).

\subsection{Person Job-fit}

Person job-fit is a correspondence between the knowledge, skill and ability of an individual to claim his work demand (Sekiguchi, 2004). Young \& Ryerson (1986) defines person job-fit is on the specific requirements of the work to a policy operated through the correspondence of knowledge, skills and abilities of the individual against the needs of the job. According to Kristof (1996) person job-fit can be defined as the relationship between the ability of individuals to specific job requirements and the desire of individuals to attribute specific work.

In an organization, the correspondence can be determined by various methods based on the aspects that are assessed in the work environment. Person job-fit is one of the dimensions of a correspondence which is researchers focused in this study. Person job-fit dimension is found in environment job-fit perspective. Person job-fit is defined as the relationship between the ability of individuals to specific job requirements and the desire of individuals to attribute a specific job (Edwards, 1991; Kristof, 1996).

Person job-fit is also known as a bridge between the individual criteria and work or tasks performed in the workplace. Person job-fit can be operated as a compromise between the knowledge, skills and abilities to the needs of the demands of work (Caldwell \& O'Reilly, 1990; O'Reilly, Chatman, \& Caldwell, 1991). Edwards (1991) defines person job-fit as a compromise between individual capabilities and requirements of the work or the will or desire. Edwards (1991) has outlined two basic concepts in person-job compatibility. First, the correspondence needs capacity demands (demands-abilities fit) which means the knowledge, skills and abilities of an employee who can equal to a work that is required. Second, compatibility requirements, providing for ('needs-supplies fit') which means desire, needs and wants of employees is appropriate to the task to be performed. Compatibility requirements, in particular the ability claim is based on the dimensions of the knowledge, skills and abilities of individuals and also duties and requirements of the organization. Compatibility requirements, preparation needs, focuses on the individual needs and desires, the desires of the value or type the desired value in the organization. Studies have shown that work-related constructs are related to the behavior of the strongest in the work, in which the related constructs of organization is most closely associated with the behavior in the organization (Shore \& Martin, 1989). Therefore, based on the domain of correspondence, job satisfaction can be linked strongly to the correspondence of individual jobs. In addition, person job-fit can have a significant impact on an individual's work performance.

\subsection{School Culture}

The school culture is the personality of the school that influence the way a job is done. The school culture is often described with a concept 'this is how we do the work here' (Ruhani, 2009). Luthans (1995) highlighting six key characteristic from school culture, namely (1) observed behavioral regularities; the mode of action of the members who are observed (the senior teachers in school), (2) norms of behavior, (3) dominant values; core values of the practice, (4) philosophy; policies with respect to the confidence of the school, (5) rules or guidelines strongly held by the school and (6) organizational climate that overall feeling that is reflected and transmitted through the space, how to interact with members of the school.

Some aspects of the school context have attracted researchers to look at the impact on the perspectives and practices of new teachers in the school. School culture, school rules, curriculum, time allocation, teaching, the influence of teachers, relationships with parents, classroom ecology, colleagues, school characteristics, patterns of school administration, class size and school calendar are school context variables which plays an important role in the process of adjustment and new teacher work (Bullough, 1989; Crow, Robert, \& Knowles, 1989; Hebert \& Worthy, 2001). According to Deal \& Peterson (1999) culture is a complex whole entity. It covers aspects such as knowledge, belief, art, morals, laws, norms, customs and other skills and habits inherited or acquired and applied in our lives. All of these elements are important in describing a thing or behavior (Deal \& Peterson, 1999). Banks (1993) and Peterson \& Deal (1998) also define the culture of the school as a social system that has a culture of its own. It consists of institutional norms, social structure, beliefs, values, symbols, traditions, goals and objectives of their own to form their own organization.

According to Comer \& Kelly (1980) educators need to work together to create a school that is productive and livable. 'Research for Better School' has done a study on 200 outstanding schools in the United States and has enlisted some cultural traits possessed by the schools of the school to provide maximum facilities to the students, the curriculum focuses on the content and skills, leadership providing vision and resources, teachers are provided 
with sufficient resources and the school does not accept any excuse (Don \& David, 2006). All these features are connected to a positive school culture and balanced adjustment leading to new teachers.

The importance of culture in schools has also been agreed and strengthened by Stolp (1994) describes a healthy school culture has a strong relationship with academic achievement and motivation, productivity and satisfaction of teachers. As conclusion school culture is covering the school practices, collective trust, communication systems and climate of a school that practiced collectively.

Hoy and Miskel (in Prestorius \& Villiers, 2009, p. 33) describes school climate as the heart and soul of a school. School culture in this study look the school as a community. It consists the dimensions of school climate are community learning and collective problem solving. It is measured using a combination of School Culture Scale Indicators by McLaughlin \& Talbert (2003) and Hoy, Smith, \& Sweetland (2002).

\section{Conclusion and Implications for HRD Theory and Practice}

This article has aimed to develop a theoretical framework for measuring new teacher's work adjustment. The article concludes that the individual factors (self-efficacy and person job-fit) and organizational environmental factors (mentoring and school culture) could potentially predict work adjustment of new teachers (see Figure 2). The domains of individual-environmental interactions are in line with the three core areas of HRD, as work adjustment or adaptation is now being addressed in the implementation of HRD practices: (1) personnel training and development; (2) career development and; (3) organizational development.

The present framework suggests specific individual's factors and organizational environmental factors can lead to better work adjustment. New teachers in school with higher levels of self-efficacy and higher levels of person job-fit are believed to achieve better work adjustment. Effective mentoring programme and positive school culture are also believed to lead better work adjustment among new teachers.

Hence, specific programs for personnel training and development for new teachers such as confidence stimulation and job-related knowledge and skills training should be provided by the organizations. These can help to build their self-efficacy to higher level and to identify their person job-fit level. Organizations also play important role through organizational development interventions such as mentoring to guide the new teachers in their career planning and throughout their career path. Guidance and feedbacks from the supervisors and superiors on new teacher's performance would allow new teachers to lead better work adjustment and thus avoid the formation of low person job-fit perception. Author further conclude that schools should take into consideration the programs designed for new teachers. A better program would lead to better work adjustment of new teachers.

\section{References}

Abell, D. (1995). O’Brien. SK Abell, DR Dillon, CJ Hopkins, WD McInerney, DG O'Brien. Somebody to count on mentor/intern relationships in a beginning teacher internship program. Teaching and Teacher Education, 11(2), 173-188. http://dx.doi.org/10.1016/0742-051X(94)00025-2

Anderson, E. M., \& Shannon, A. L. (1988). Toward a Conceptualization of Mentoring. Journal of Teacher Education, 39(1), 38-42. http://dx.doi.org/10.1177/002248718803900109

Aryee, S., Wyatt, T., \& Stone, R. (1996). Early Career Outcomes of Graduate Employees: The Effect of Mentoring and Ingratiation. Journal of Management Studies, 33(1), 95-118. http://dx.doi.org/10.1111/j.1467 -6486.1996.tb00800.x

Bandura, A. (1977). Self-efficacy: Toward a unifying theory of behavioral change. Psychological review, 84(2), 191. http://dx.doi.org/10.1037/0033-295X.84.2.191

Bandura, A. (1982). Self-efficacy mechanism in human agency. American psychologist, 37(2), 122. http://dx.doi. org/10.1037/0003-066X.37.2.122

Bandura, A. (1986). Social foundations of thought and action. Englewood Cliffs, NJ Prentice Hall.

Bandura, A. (1997). Self-efficacy: The exercise of control. Macmillan.

Banks, J. A. (1993). Multicultural education: Historical development, dimensions, and practice. Review of Research in Education, 3-49.

Black, J. S. (1988). Work role transitions: A study of American expatriate managers in Japan. Journal of International Business Studies, 19(2), 277-294. http://dx.doi.org/10.1057/palgrave.jibs.8490383

Brill, S., \& McCartney, A. (2008). Stopping the revolving door: Increasing teacher retention. Politics \& Policy, 36(5), 750-774. http://dx.doi.org/10.1111/j.1747-1346.2008.00133.x 
Bullough, R. V. (1989). First-year teacher: A case study. Teachers College Press.

Caldwell, D. F., \& O'Reilly, C. A. (1990). Measuring person-job fit with a profile-comparison process. Journal of Applied Psychology, 75(6), 648. http://dx.doi.org/10.1037/0021-9010.75.6.648

Comer, J. P., \& Kelly, H. (1980). School power: Implications of an intervention project. Free Press New York.

Coppel, D. B. (1980). The relationship of perceived social support and self-efficacy to major and minor stresses. University of Washington.

Corcoran, E. (1981). Transition shock: The beginning teacher's paradox. Journal of Teacher Education, 32(3), 19-23. http://dx.doi.org/10.1177/002248718103200304

Crow, N., Robert, J. B., \& Knowles, J. (1989). Teacher self-concept and student culture in the first year of teaching. The Teachers College Record, 91(2), 209-233.

Dawis, R. V., \& Lofquist, L. H. (1984). A psychological theory of work adjustment: An individual-differences model and its applications. University of Minnesota Press Minneapolis, MN.

Deal, T. E., \& Peterson, K. D. (1990). The Principal's Role in Shaping School Culture.

Deal, T. E., \& Peterson, K. D. (1999). Shaping school culture: The heart of leadership. ERIC.

Don, A. I. Y., \& Daud, Y. (2006). Kepimpinan \& Pembangunan Pelajar Sekolah di Malaysia. Kuala Lumpur: PTS Profesional

Dropkin, S., \& Taylor, M. (1963). Perceived problems of beginning teachers and related factors. Journal of Teacher Education, 14(4), 384-390. http://dx.doi.org/10.1177/002248716301400406

Edwards, J. R. (1991). Person-job fit: A conceptual integration, literature review, and methodological critique. John Wiley \& Sons.

Flores, M. A., \& Day, C. (2006). Contexts which shape and reshape new teachers' identities: A multi-perspective study. Teaching and teacher education, 22(2), 219-232. http://dx.doi.org/10.1016/j.tate.2005.09.002

Gist, M. E., Mitchell, T. R., \& Mitchell, R. (1992). Self-efficacy: A theoretical analysis of its determinants and malleability. Academy of Management review, 17(2), 183-211.

Hebert, E., \& Worthy, T. (2001). Does the first year of teaching have to be a bad one? A case study of success. Teaching and teacher education, 17(8), 897-911. http://dx.doi.org/10.1016/S0742-051X(01)00039-7

Hobson, A. J., Ashby, P., Malderez, A., \& Tomlinson, P. D. (2009). Mentoring beginning teachers: What we know and what we don't. Teaching and teacher education, 25(1), 207-216. http://dx.doi.org/10.1016/j.tate. 2008.09.001

Hoffman, J. V., Edwards, S. A., O’Neal, S., Barnes, S., \& Paulissen, M. (1986). A study of state-mandated beginning teacher programs. Journal of Teacher Education, 37(1), 16-21. http://dx.doi.org/10.1177/0022487 18603700104

Hoy, W. K., Smith, P. A., \& Sweetland, S. R. (2002). The development of the organizational climate index for high schools: Its measure and relationship to faculty trust. The High School Journal, 86(2), 38-49. http://dx.doi.org/10.1353/hsj.2002.0023

Ingersoll, R. M., \& Strong, M. (2011). The Impact of Induction and Mentoring Programs for Beginning Teachers A Critical Review of the Research. Review of educational research, 81(2), 201-233. http://dx.doi.org/10. 3102/0034654311403323

Johnson, S. M., \& Birkeland, S. E. (2003). Pursuing a "sense of success": New teachers explain their career decisions. American Educational Research Journal, 40(3), 581-617. http://dx.doi.org/10.3102/0002831204 0003581

Kristof, A. L. (1996). Person-organization fit: An integrative review of its conceptualizations, measurement, and implications. Personnel psychology, 49(1), 1-49. http://dx.doi.org/10.1111/j.1744-6570.1996.tb01790.x

Kwan, T., \& Lopez-Real, F. (2005). Mentors' perceptions of their roles in mentoring student teachers. Asia-Pacific Journal of Teacher Education, 33(3), 275-287. http://dx.doi.org/10.1080/13598660500286267

Lofquist, L. H., \& Dawis, R. V. (1969). Adjustment to work. Appleton-Century-Crofts Nueva York.

Louis, K. S. (1998). Effects of Teacher Quality of Work Life in Secondary Schools on Commitment and Sense of Efficacy. School Effectiveness and School Improvement, 9(1), 1-27. http://dx.doi.org/10.1080/092434598 0090101 
Luthans, F. (1995). Organizational behavior.

McLaughlin, M., \& Talbert, J. (2003). Reforming districts: How districts support school reform. Seattle, WA: Center for the Study of Teaching and Policy.

O’Reilly, C. A., Chatman, J., \& Caldwell, D. F. (1991). People and organizational culture: A profile comparison approach to assessing person-organization fit. Academy of management journal, 34(3), 487-516. http://dx. doi.org/10.2307/256404

Peterson, K. D., \& Deal, T. E. (1998). How leaders influence the culture of schools. Educational Leadership, $56(1), 28-30$.

Pitton, D. E. (2006). Mentoring novice teachers: Fostering a dialogue process. Corwin Press.

Ramey-Gassert, L., \& Shroyer, M. G. (1992). Enhancing science teaching self-efficacy in preservice elementary teachers. Journal of Elementary Science Education, 4(1), 26-34. http://dx.doi.org/10.1007/BF03173752

Sekiguchi, T. (2004). Toward a dynamic perspective of person-environment fit. Osaka keidai ronshu, 55(1), 177-190.

Shore, L. M., \& Martin, H. J. (1989). Job satisfaction and organizational commitment in relation to work performance and turnover intentions. Human relations, 42(7), 625-638. http://dx.doi.org/10.1177/00187267 8904200705

Simpson, T., Hastings, W., \& Hill, B. (2007). "I knew that she was watching me": The professional benefits of mentoring. Teachers and Teaching: Theory and practice, 13(5), 481-498. http://dx.doi.org/10.1080/135406 00701561695

Stolp, S. W. (1994). Leadership for school culture.

Veenman, S. (1984). Perceived Problems of Beginning Teachers. Review of Educational Research, 54, 143-178. http://dx.doi.org/10.3102/00346543054002143

Webb, R. B., \& Sherman, R. R. (1989). Schooling and Society. New York: Mac Millan.

Wilkinson, G. A. (2009). Supportive induction slows the revolving door. Research in Comparative and International Education, 4(1), 97-110. http://dx.doi.org/10.2304/rcie.2009.4.1.97

Wood, R., \& Bandura, A. (1989). Impact of conceptions of ability on self-regulatory mechanisms and complex decision making. Journal of personality and social psychology, 56(3), 407. http://dx.doi.org/10.1037/00223514.56.3.407

Young, I. P., \& Ryerson, D. L. (1986). Teacher selection: Legal, practical, and theoretical aspects. University Council for Educational Administration University Park, PA.

Zin, R. M. (2009). Budaya Sekolah: Implikasi terhadap proses pmbelajaran secara mengalami. Jurnal kemanusiaan, 13, 63-78.

\section{Copyrights}

Copyright for this article is retained by the author(s), with first publication rights granted to the journal.

This is an open-access article distributed under the terms and conditions of the Creative Commons Attribution license (http://creativecommons.org/licenses/by/3.0/). 